\title{
Karl Barth and the future of dogmatic theology
}

\author{
Alasdair I C Heron ${ }^{1}$ \\ Friedrich-Alexander-Universität, Erlangen-Nürnberg (Germany) \\ Research Associate: Department of Systematic Theology \\ University of Pretoria
}

\begin{abstract}
The article discusses Karl Barth's contribution to dogmatic theology. It describes Karl Barth's personality and shows how his theology was put to practice in writing, in teaching, in debate, in conflict, in friendship and in opposition. Some negative comments on Barth are for example levelled at his liturgical insensitivity, unbalanced and exclusive emphasis on preaching, and his individualistic dislike of the established church, its governing structures and baptismal practice. The article focuses on Barth's impulses for the discipline of dogmatics and demonstrates developments and directions in his work. Critically reservations regarding instances where it might seem better for theologians not to follow Barth, are specified. The article also offers a glimpse into the future of dogmatic theology seen through the lens of Karl Barth.
\end{abstract}

\section{INTRODUCTION}

Assessments of significance depend at least in part on the standpoint of the observer and the context of interpretation. The more prominent the object, the more perspectives are likely to be available. That is certainly the case with Barth, precisely because he still, thirty years after his death, stands out as a major figure - to put it no more strongly - in

1 Prof Dr Alasdair I C Heron (the Institut für Systematische Theologie Lehrstuhl für Reformierte Theologie Friedrich-Alexander-Universität, Erlangen-Nürnberg, Germany) is a member of the International Advisory Board of HTS Theological Studies. Prof Heron participates as research associate of Prof Johan Buitendag (Department of Systematic Theology, University of Pretoria) in the research project "Relevance and Identity of the Church". Prof Heron presented this paper as a public lecture at the Faculty of Theology, University of Pretoria, on 3 September 2001. 
the history of theology in the twentieth century. A major figure - also a disputed figure, hailed by some as the modern church father, dismissed by others as out of touch and out of date even in his own day, to say nothing of trente ans après.

These thirty years have been the period of my own involvement in theological research and teaching - a period in which a not uncritical engagement with Barth has been one recurrent activity. It was within a few weeks of beginning doctoral study in Tübingen in 1968 that I heard from Jürgen Moltmann of Barth's death the day before. That puts me in the generation of those who began theological work to some degree under Barth's shadow and in awareness of his impact, but who never actually met or heard him in the flesh. My acquaintance with him is strictly either literary or secondhand, through my contacts and friendships with many who did know him or studied with him.

\section{KARL BARTH - THE PERSON}

This limitation has perhaps both a negative and a positive aspect - at least for the purpose of this paper. Barth was by all accounts a fascinating, surprising and sometimes provocative person, a man whose theology was lived and practised in writing, in teaching, in debate, in conflict, in friendship and in opposition. Not for nothing did he choose the title Theologische Existenz Heute - "theological existence today" - for his famous manifesto of June 25th 1933 which became the first of a long line of contributions to the series bearing that name. Testimonies abound to his ability to inspire students to take theological thought and work seriously, to his mischievous sense of humour, to his willingness to question, question, question, not destructively but - in the proper sense of the word - critically. Anecdotes about him are legion and lose nothing in the telling even decades later, for example My Father-In-Law. Memories of Karl Barth of M Zellweger-Barth and Glaubensheiterkeit. Karl Barth: Erfahrungen und Begegnungen of E Busch.

The person (and the personality) with his interest for literature and music especially Mozart! - to say nothing of the history of the American Civil War, was a fascinating influence on generations of students and colleagues in Germany, Switzerland and beyond. Equally gripping were the controversies in which he became involved - 
with Gogarten, with Brunner, with Bultmann, with Niebuhr. All of that, however, is history, history to which we now have only indirect access. The negative consequence of that is that we increasingly only have a truncated Barth before us - the work rather than the man. The positive side is that it puts me in the same boat as those for whom this paper is being written - and that Barth himself would have insisted that the work he attempted to do, especially in dogmatic theology, was his primary commitment and main contribution.

What then was Barth's contribution to dogmatic theology and what is likely to be its enduring significance? The first question is easier to tackle than the second; indeed the second faces us with all the buzzing and blooming confusion of contemporary theology and that is a much harder field to survey than, say, the shift from German liberal theology to the new theological climate of Barth and his "dialectical" allies in the 1920s. It is further complicated by the fact that the question of Barth's likely lasting importance tends to look very different depending on the setting in which it is posed, whether in Germany or Switzerland, in Britain or America, in Africa or Asia. Another complicating factor is ecclesiastical or confessional: the process of "reception" of Barth's theology tends to be rather different in reformed, lutheran, anglican, catholic or orthodox traditions. Perhaps, however, we can seek some leverage on the second question by focussing on the first.

\section{PERSONAL INVOLVEMENT WITH KARL BARTH}

\subsection{Autobiographical retrospect}

Let me begin with a little autobiographical retrospect - an attempt to think back on how Barth entered my own field of view. It must have been some time in the late 1950s that my father - a Scottish parish minister with a great interest in doctrinal theology mentioned the name of Karl Barth and on my asking who he might be replied simply "the greatest theologian of the first half of this century". For a schoolboy that was an impressive testimony from an unimpeachable source. My father was not uncritical of Barth - particularly on the subject of infant baptism - and found the few volumes of the Church Dogmatics that he had been able to afford quite excessively lengthy and wordy, 
comparing Barth here unfavourably to Emil Brunner; but he still regarded Barth as the greater of the two, as the doctor ecclesiae of his day, as the towering figurehead of dogmatic theology. In this, as I later found, my father was representative of many of the ablest Scottish theological students of the 1930s - the years when Barth was really beginning to become well known in Britain, and especially in Scotland. Useful on this is a recent German dissertation: Anne-Kathrin Finke, Karl Barth in Grossbritannien. Rezeption und Wirkungsgeschichte.

As time passed I went on to study Divinity in New College, Edinburgh, and came under the aegis of Thomas $\mathrm{F}$ Torrance, the most redoubtable and most massively learned of all Barth's disciples in that generation. Two abiding memories are of learning German using Dogmatik im Grundriß as the reading text and of compiling a précis of Church Dogmatics I/2 §15: “The Mystery of Revelation", that being the prescribed exercise to introduce us to dogmatic theology. It was an exercise that could - and in my case probably did - mark one for life. Having previously studied classics and philosophy, I had a largely exegetical, liturgical and homiletical conception of theology: here I was confronted with tough, biblically and historically shaped theological ideas and questions demanding thorough and serious discipline in their handling - a handling intended to think through and if possible beyond positions attained in the past. In my own small way I was making a similar discovery to that which Barth describes in his foreword to Ernst Bizer's revision of Heppe's Reformed Dogmatics (Heppe 1950:v-vii), - that theology is a serious and responsible intellectual discipline with its own proportions, symmetry and elegance, no less demanding than the questions of contemporary philosophy which had occupied me in the previous years.

At the same time I became well aware that "Barthianism" was often more a term of opprobrium than of praise in the British and American context. Barth's frontal attacks on natural theology were a thorn in the eye of a style of philosophical theology which had such a long tradition in Britain in both anglican and reformed dress. Similarly, Barth's critique of "religion" could not but be found unsympathetic by the advocates, coming to prominence in Britain in the 1960s, of "religious studies" rather than "confessional dogmatics". In both respects I soon found that much criticism and rejection of Barth was based more on ill-informed caricature than on any real attempt to understand him and that 
the points he was making deserved to be taken more seriously and grasped in a more differentiated way; but of course substantial issues remained (and still remain) in these areas. On another tack, we knew even in Edinburgh that the post-war generation of German theological students was much more deeply coloured by the Bultmann school than by Barth, though a certain reaction associated with names such as Pannenberg, Moltmann and Jüngel was beginning to make itself felt. We did not on the whole hear anything very much about the Barthian theologians still active in Germany - Otto Weber, for example, or Walter Kreck. If anything, the greatest impact out of Germany (apart from Bultmann's) came from Gogarten via Harvey Cox and Cox's popularisation of the theme of secularisation (Cox 1965). Yet there was also Barth's Dogmatics, complete in English by the end of the 1960s, a monument that could not be overlooked and a mine of information and argument on all kinds of theological issues - which is how, like many others, I tended to use it. "Da magistrum!" meant not, as when Cyprian said it, "Give me Tertullian”, but "Look up Barth!”

Edinburgh dogmatics under Torrance was not, however, characterised by any kind of uncritical Barthianism. A proportion of the students came from a strongly conservative background in which Calvin and reformed orthodoxy set the tone and Barth was looked upon as rather dangerously liberal - an attitude I later learned was shaped by theologians such as Cornelius van Til and others in the Dutch reformed tradition. More importantly, however, Torrance himself was a much too independent thinker to be content with simply parroting Barth or encouraging his students to do the same. In the theology I learned in New College in the 1960s (and taught there in the 1970s) Barth was an important source and a significant authority, but one with whom one had a perfect right to disagree and who was certainly not to be regarded as having said the last word on any subject. It may seem banal to say so, but we were not "Barthians" in any narrow sense of the word at all in spite of the respect in which we held him. My own special subjects in the final honours examination in dogmatics were Calvin and Tillich; I went on at Torrance's encouragement to do research in patristics; my first published article ventured to attempt to correct Barth on the filioque question with the help of Anselm, Augustine and Vladimir Lossky (Heron 1971:149-166). That was characteristic of Torrance's influence. A number of factors probably contributed to this - Torrance's critical loyalty to the tradition of Scottish reformed theology, with which Barth not 
surprisingly had only very sketchy familiarity, was one. Another was the much greater breadth of Torrance's own historical and ecumenical theological studies from his student days onwards, as compared with Barth's relatively late entry into the scene of academic theological teaching as a virtual autodidact in his mid-thirties. Most significant of all, perhaps, was Torrance's deliberate pushing far beyond Barth on the interface between theology, specifically dogmatic theology, and the thinking of natural science. ${ }^{2}$

After moving to Erlangen in 1981 I found myself in a rather different setting. On the one hand the general retrospective view and evaluation of Barth current in German theology tended to approximate to what I had first heard in my father's study more than twenty years before: Barth had been the most influential single figure in evangelical theology in the first part of the century. The emphasis was on the "had been". A generation of younger systematic theologians, some of them virtually unknown outside central Europe, were busily working away in research and teaching in the field of dogmatic theology. Some were conscious of a debt to Barth, others were more inclined to pass him by. I began to see more clearly what it meant that Barth had been Swiss, not German; that he had been Reformed, not Lutheran; that he had been clearly identified with the Confessing Church, which had never been more than a minority in the German Evangelical Church in the Nazi period; that after the war he had been prominently allied with the continuing representatives of that strand - for example Martin Niemöller - in their opposition to the restoration politics of other church leaders; that his vocal criticism of German rearmament and his rejection of the politics of the Cold War had not made him popular everywhere in the German church. In much the same way his public opposition to fascism had made him politically suspect in Switzerland before 1945, his refusal equally to condemn communism in the years thereafter. The more I learned about all this personal history, the more I began to appreciate Barth's only half-humorous complaints in later years about being excluded from the company of respectable theology - complaints which hardly make any sense to anyone who has only heard of Barth that he

\footnotetext{
2 To mention only a few of Torrance's contributions in this area: Theological Science (London: Oxford University Press, 1969); Space, Time and Incarnation (London: Oxford University Press, 1969); Theology in Reconciliation (London: Geoffrey Chapman, 1975); Christian Theology and Scientific Culture (Belfast: Christian Journals, 1980); Transformation and Convergence in the_Frame of Knowledge (Belfast: Christian Journals, 1984); Reality and Scientific Theology (Edinburgh: Scottish Academic Press, 1985); The Christian Frame of Mind (Colorado Springs: Helmers \& Howard, 1989).
} 
was "the greatest theologian of his age" or the leader of "neo-orthodoxy" - incidentally a term at which Barth could only laugh (Barth 1969:34).

\subsection{Barth - The Outsider}

In many ways Barth was made to feel and felt himself to be an outsider, always one who was content to go his way as "God's cheerful partisan".

Two observations can perhaps help to illustrate this. I was fortunate in arriving in Erlangen in 1981 in time to become a close friend of two of the Bavarian Lutheran ministers who had been most active in the Confessing Church - Karl Steinbauer and Walter Höchstädter. Both published their memoirs before they died, and they are a powerful testimony (see Höchstädter 1983; Steinbauer 1983-1987). More powerful still was their personal witness to a time when, as Arthur Cochrane has said, the Confessing Church had nothing but the Word of God to live from (see Cochrane 1962). Both men had the highest regard and appreciation for Karl Barth for his role in Germany in the years before his expulsion from his chair in Bonn in 1935 and for his encouragement from Basel in the years following. Witness and faithfulness were what they had learned, not only from Barth, but also from Barth. The theology represented in my own faculty of Erlangen in that period - that of Werner Elert and Paul Althaus - was, to put it mildly, of a very different stamp - and that was the official theology of the Lutheran Church in Bavaria. ${ }^{3}$ All in all, a reflection in nuce of the situation in which Barth found himself as a Swiss Reformed theologian in a context dominated by German Lutherans.

The second observation is, from my perspective at least, somewhat more critical Barth's outsider position seen, as it were, from its more deficient side. It is aptly characterised in a letter written from Basel by Reinhold Niebuhr to his wife Ursula in 1947. On March 30th Niebuhr had complained to her about what today might be described as a negative liturgical experience (Niebuhr 1989:237-239):

This morning I went to a reformed church confirmation service, conducted very much as I used to conduct them. But the service left me unsatisfied. It

\footnotetext{
3 See e g R P Ericksen, Theologians under Hitler: Gerhard Kittel, Paul Althaus and Emanuel Hirsch (New Haven: Yale University Press, 1985); B Mensing, Pfarrer und Nationalsozialismus: Geschichte einer Verstrickung am Beispiel der Evangelisch-Lutherischen Kirche in Bayern (Göttingen: Vandenhoek und Ruprecht, 1998); B Hamm, Werner Elert als Kriegstheologe: Zugleich ein Beitrag zur Diskussion "Luthertum und Nationalsozialismus", KZG 11/2 (1998), 206-254.
} 
was so barren and unimaginative and the sermons - there were two - so dull and commonplace. The Swiss are not strong on poetry or on any of the graces of the spiritual life. They are terribly earnest and realistic and dull, or so it seems to me.

To be even-handed: these letters of Niebuhr's are also peppered with critical observations on Dutch Calvinism, German and Scandinavian Lutheranism and the sentimentalism of Scottish theology (Niebuhr 1989:225, 235). He then continues the story on April 2nd:

Two of your letters forwarded from Geneva were handed to me by Karl Barth on my arrival here. ...

He is, of course, a very charming man but also very honest, and we had some very searching discussions the upshot of which was that he criticized me for trying to make a new wisdom out of the foolishness of the Gospel and I accused him of forgetting that the Gospel was really the wisdom as well as the power to them that believe. This involved the whole question of the relation of faith to philosophy on the one hand and to ethics and politics on the other. I found it most stimulating and helpful. I told him I was too much of a preacher not to look for points of contact between the truth of the Gospel and the despair of the world. He was surprised that I preached, and I told him that you accused me of preaching like Schleiermacher on religion to its intellectual despisers. This pleased him very much and he repeated, "Did she say that, really?"

He, like all the Swiss and all the continental Calvinists, has no sense for liturgy and was indifferent toward my criticism of the barren confirmation service I attended on Sunday. He depends upon the sermon to maintain faith. I do not think that is enough though it is just as good as a liturgical service with no real sermon. That is I suppose a kind of dividing line between us as it is between England and the Continent. I am continental of heart and faith but not so (after being corrupted by you) that I could stand these services long. Another thing about Karl Barth. He has developed curious sectarian tendencies having thrown the church in an uproar here by his criticism of infant baptism. Now he is on the Congregational tack, insisting that the real church is only in the simple community of faith in the congregation and that theologians, bishops, secretaries imagine they are the church. I went after him on these issues pretty hard though I must grant he is right in regard to the 
emphasis that faith, hope and love in the life of believers are the real substance of the church and that all else is superstructure.

(Niebuhr 1989)

\subsection{Barth - The liturgist}

Liturgical insensitivity, unbalanced emphasis exclusively on preaching, an individualistic dislike of the established church, its governing structures and baptismal practice - these are the charges leveled by Niebuhr at Barth and, on the first two points, at continental Calvinism generally. It must be admitted that there is a good deal of truth and weight in them. On the liturgical aspect - though some things have changed here in the last fifty years - there had since the nineteenth century been a wide gulf between the fresh liturgical awakening in the reformed churches in the anglo-saxon sphere and the continuing heavily didactic style of continental reformed churches; and Barth simply reflected that. His journeys abroad were probably mostly too brief to allow him to become familiar with more alien liturgical traditions, at which he was more inclined to poke fun (see Busch 1976:399, 567). Yet at the same time, at least in his later years, he would frequently observe that far more of substance had been preserved in the Roman Catholic church than in Protestantism - a comment which would seem to stand in some tension with his rather individualistic ecclesiology as Niebuhr accurately saw it. Perhaps it is simply too much to expect anyone, even a Karl Barth, to be entirely consistent in such preferences and judgments, involving as they do many complex and often exceedingly subjective factors.

That is perhaps enough of personal retrospect, though all the themes touched upon could be developed at much greater length. It is time to look more closely at Barth's contribution to dogmatic theology.

\section{BARTH'S CONTRIBUTION TO DOGMATIC THEOLOGY}

Barth's work can be seen from many different aspects; here I can do little more than list those points which seem to me of abiding importance and relevant for the future orientation of dogmatic theology. These concern first of all Barth's impulses for the discipline of dogmatics as such; second particular developments and directions to be seen 
in his work which represent an advance on what had gone before; third, critical reservations where it might seem better that theology should not follow Barth.

\subsection{Barth's impulses for the discipline of dogmatics}

It was no part of Barth's original intention to become a dogmatic theologian. His Commentary on Romans - The Epistle to the Romans - grew out of frustration with a purely objective, distanced, historical approach to the understanding of biblical texts which left them having nothing to say to preacher and congregation in their contemporary context. Barth attempted to listen out of that context to what he could hear in Paul addressing Barth's own time as the Word of God. Lively and relevant theology was what he was after as opposed to archaeological study of documents from the past. This applies to both the first and second editions of Barth's Romans, though the theological and hermeneutical perspective had changed fairly radically between them. The heavy existentialism, the echoes of Overbeck and Dostoievsky, above all the Kierkegaardian emphasis on the "absolute qualitative difference" and "vertically from above" are features of the second edition rather than of the first, though it was the first - today almost totally forgotten - which led to Barth's call to the professorship of reformed theology in Göttingen.

\subsection{Particular developments and directions to be seen in his work}

This concern to practise a relevant and lively theology of the Word of God remained central to Barth's work for the rest of his life, but he was compelled by the circumstances and responsibilities of his new position as an academic teacher to expand his arsenal of resources and his stock of information. This involved him in the years in Göttingen in continuing and extending his biblical work, in deepening his acquaintance with early reformed theology - notably Zwingli, Calvin and the Heidelberg Catechism, all themes of lectures in Göttingen - and in making a first effort at writing a dogmatics (Freudenberg 1997; Barth 1991).

A few years later, in Münster, intensive if critical dialogue with Roman Catholic theology and with the heritage of scholastic medieval theology, especially Anselm and Aquinas, were added. Here too in 1927 the first volume of his Christian Dogmatics was 
published - only to be radically recast and massively expanded as Church Dogmatics I/1 and $\mathrm{I} / 2$ in the 1930s. With that the course for his future work was set and work on the Dogmatics became the main - though never the only - priority in the remaining decades of his life.

Some features of the style and pattern of the Christian Dogmatics deserve comment - not least as they can puzzle readers unfamiliar with this genre. The entire work, though incomplete even at the end, was conceived on a plan with a clearly developing structure:

- The Doctrine of the Word of God (as Prolegomena)

- The Doctrine of God

- The Doctrine of Creation

- The Doctrine of Reconciliation

- The Doctrine of Redemption.

This structure broadly corresponds, like other classical works of dogmatics, to the structure of the creeds and the pattern of the history of salvation - or as Barth preferred to call it, "God's history with us". Even the structure, however, has two distinctively modern features: the emphasis on the Trinitarian ground of the divine self-revelation in volume one as the essential precondition of any possibility of genuine theology; and the emphasis on the theme of reconciliation integrating the doctrines of the person and work of Jesus Christ in volume four. Both reflect Barth's concern to hold and think together aspects too often separated off from each other and treated separately. In the same way, Barth sets out in each volume consciously to integrate dogmatics and ethics as two aspects of Christian response to the divine address and action, rather than as, say, "theological or doctrinal theory" and "Christian practice". It is incidentally often overlooked by those who accuse Barth of representing an authoritarian "theology from above" what a large place in his discussion of dogmatics and ethics is given to the theme of freedom - God's freedom and ours. This too is a distinctively modern note in Barth's theology: He too was inter alia a child of the Enlightenment and could say of himself "Ich bin auch ein Liberaler!” (“I'm a liberal too!"). 
Three aspects of the literary construction of the Dogmatics are relevant. The first is simple enough, but very often overlooked. Barth divides his exposition into lengthy paragraphs (numbered sequentially throughout the entire Dogmatics as $\S 1, \S 2$ and so on) and prefaces each not only with a title (e g $\S 1$ The Task of Dogmatics) but also with a summary proposition which gathers together the themes and frequently illuminates the structures of the paragraph. These headings and propositions are usefully collected together at the beginning of the index volume (Barth 1977:1-13).

Second, Barth used what he sometimes called a "spiral method", going over a theme in its various aspects not only once but twice or more from different perspectives, commonly numbering the different steps to facilitate recognition when they arose again sometimes many pages later.

Third there is the typographical distinction between the large print and the small print. Essentially, the large print contains Barth's own reflection and argument and can be read as a continuous text. Detailed excursions into biblical exegesis or the history of theology or controversial issues on the boundaries between theology and other disciplines go into the small print - sometimes at very considerable length - whereby these passages are usually to be taken as supporting and expanding the previous section of large print.

These points may seem trivial and elementary, but I make them here for two reasons. First it has been my experience in using the Church Dogmatics as a text for theological teaching that contemporary readers accustomed to briefer and more concentrated media of communication - especially in textbooks - need to take advantage of all these clues in order to keep their bearings when trying to follow Barth's disquisitions. Second, they do highlight the fact that Barth's dogmatics, for all the modernity of much of the content, belongs to a genre and reflects a tradition and style of lecturing, teaching and writing which is scarcely practised today and arguably is no longer effective as a paedagogical method. The obverse of that coin, however, is that it was probably only because he was prepared to take such a long breath, to reflect at such length and detail, to argue from this side and from that, to go round and round questioning and rethinking, that Barth was able to reformulate and cast fresh light upon many of the central themes and issues of Christian dogmatics and to re-establish dogmatic thinking as a dynamic and creative enquiry at the heart of Christian theology, 
indeed as an instrument of theological and ecclesiastical self-correction and as such as a discipline pointing forwards rather than backwards. That is why it is still worth the effort and trouble of going to school with him and reflecting with him instead of succumbing to the temptation of simply picking up his main conclusions and going on from there.

The conclusions are nevertheless significant. Space permits here only the briefest mention of some of the issues radically recast and freshly illuminated by Barth. Two have been touched upon already: the integration of Trinitarian thinking with the understanding of revelation and the dynamic combination of the traditional doctrines of the person and work of Jesus Christ, to which we have also added the unifying of dogmatics and ethics. The same style of integrating and unifying reflection is splendidly demonstrated in two chapters of volume two - the doctrine of God as "the One who loves in freedom" and the reworking of the theme of the divine election. This latter is sometimes (wrongly) seen as merely a problem for reformed, specifically Calvinist theology; in fact it is a problem for the entire Augustinian tradition of Western theology, both Roman Catholic and Protestant, though more often ignored than addressed. Barth's detailed handling of it - including perhaps some more than adventurous biblical exegesis! - may be open to criticism, but in one fundamental correction of virtually the entire previous tradition he is surely right: that both election and reprobation (God's "Yes" and "No") must first of all be understood christologically in the light of the cross and resurrection. In a similar way in volume four Barth departs from the tradition of developing the understanding of the fall and sinfulness as a prolegomenon to and precondition for the doctrine of reconciliation, and treats them instead as a reflex of the achieved reality of reconciliation. In between these, in volume three, it is above all Barth's handling of the topics of creation and covenant which reflects the same concern to unify and integrate themes more traditionally dealt with separately. One may add that Barth's daring handling of "God and Nothingness" in this volume - however problematic the exegetical basis may be here too - is a tour de force of sustained theological and philosophical reflection which shows the formerly so existentially influenced Barth countering such thinkers as Heidegger and Sartre as an intellectual equal. 


\subsection{Critical reservations}

In ways such as these the judgment seems justified that Barth has set new directions for dogmatic theology; that at any rate it cannot afford to ignore or retreat behind the challenge he represents. But are there respects in which it would do better not to follow him - or at any rate, to do so only with critical caution? I believe there are: they have all already been touched upon.

1. Barth's rejection of natural theology, his dislike of the discipline of defensive apologetics, his concern for the authenticity of dogmatics as a discipline with its own task, questions and methods free from any subservience to or dictation from other sciences are all in their own way not only understandable but justifiable. They do not, however, necessarily make dogmatic theology very capable of entering into dialogue with these other disciplines. The clearest case is the sense of relief shown by Barth when he discovers in volume three of the Church Dogmatics that he can handle the dogmatic theme of creation quite adequately without entering into any discussion with natural science, which has quite simply a different job to do. Torrance has certainly been right in seeing that dogmatic theology cannot allow itself to be bound by this restriction, that indeed impulses in Barth's own style of theological work and argument already strain against it. There is a tight-rope to be walked here; but proper insistence on the independence and integrity of dogmatics should not be pushed to the point of leaving it in a ghetto.

2. It is a commonly voiced complaint that Barth pays too little attention and does too little justice to the justifiable claims and necessary insights of the historicalcritical approach to biblical exegesis. The criticism is sometimes driven to the point of crass misrepresentation, but it is not entirely lacking in basis. Barth's use of biblical material is sometimes distinctly idiosyncratic - or, one might say, more artistic than scientific. Huge hermeneutical questions arise here and it must be admitted that Barth's exegesis, even when problematic, is at least generally provocative and interesting - which is not always the case with professed historical-critical exegesis. There is, however, room for the suspicion that Barth 
was not always sufficiently aware or critical of his own hermeneutical perspectives when drawing on biblical texts for dogmatic construction. That does not necessarily make his arguments and contributions invalid, but it does demand further consideration of the interpretative principles involved in dogmatic theology. In this connexion I should perhaps add a word on the topic which is sometimes seen (I believe, incorrectly) as the paradigm-case for this problem in Barth: his disagreement with Bultmann. That disagreement was not, however, about the principles of historical-critical exegesis, nor even primarily about Bultmann's programme of demythologisation. Barth himself testified clearly enough that his problem was Bultmann's reduction of theology to anthropology a dogmatic, not an exegetical issue. Barth states this quite explicitly in the Selbstdarstellung of 1964 from which I quote: "Was mich ihm gegenüber zur Zurückhaltung nötigte und noch nötigt, ist viel weniger seine von der Mehrzahl seiner Gegner beanstandete 'Entmythologisierung' des Neuen Testaments, als sein 'Existentialisierung' von dessen Aussagen, in der ich die Theologie nur eben neu in die Sackgasse einer philosophischen Anthropologie laufen sehe..." (What compelled and still compels my reservations about him is much less the 'demythologisation' of the New Testament to which the majority of his critics object than his 'existentialisation' of its statements, in which I can only see theology running again into the dead end of a philosophical anthropology.)

3. To return to Niebuhr's criticism mentioned above: all the aspects on which he touches - liturgical insensitivity, rejection of infant baptism, a negative attitude to governing church structures - are certainly there in Barth and can be explained and in part defended in the light of his own background and biography. They do however reflect a tendency towards individualism and congregationalism with which a Scottish Presbyterian - and doubtless others too - cannot be entirely happy. They culminate in Barth's rejection of the whole concept of sacrament in favour of the idea of "free, obedient response", with the consequent reduction of the sacramental to the ethical (see Molnar 1996). Barth's argument to this end, developed most finally in the fragment Church Dogmatics IV/4, is in its own way coherent and conclusive, consistent and programmed to come to no other result, 
so that readers can be sucked along it much like travellers in the Channel Tunnel who have no choice other than to be carried on to the end. Just this, however, highlights the necessity of reading Barth not only sympathetically but also critically - and in particular looking out for the places where the very consistency and apparent compelling necessity of the train of argument demand that one ask about the hidden presuppositions which are steering it.

It shows no lack of respect or appreciation for Barth's achievement to raise such questions. The massive scale of the Church Dogmatics can evoke the impression that it was intended to be a final word, a last statement, in the words of Thucydides a ktema es $a e i$, a possession forever. Yet they were not. They were the product of engaged and lively theological and dogmatic reflection deliberately undertaken as a critical task in the service of the church and its witness, and as such the product of a theology in via, theology on the road. Barth never had the idea that he could sum up, let alone incarcerate the whole scope of the divine revelation and invitation in Jesus Christ even in many thousands of pages. He simply went to work, day by day, week by week and year by year in the conviction that the great themes of dogmatic theology are only taken seriously when they are also thought through as deeply and carefully as possible. Barth applied himself to this task with an energy and a manifest enjoyment which - whether we follow him in this point or that - is a standing challenge to understand the work of dogmatics as he described it in Evangelical Theology as a "modest, free, critical and - above all happy science" (Barth 1963:1-12).

\section{KARL BARTH'S GLIMPSE INTO THE FUTURE}

In June 1964 Barth drafted a brief "Selbstdarstellung" in anticipation of the sixtieth anniversary of the beginning of his theological studies. In closing he hazarded a glimpse into the future; perhaps these last two paragraphs can best sum up what he believed to be his legacy and his challenge to those who would come after. I am grateful to Dr Drewes of the Barth Archive and the members of the Barth Legacy Commission for permission to quote from this as yet unpublished text. It will eventually appear in the complete edition of Barth's writings. 
I won't risk even a guess at the prospects for what I have undertaken in theology. "For everything there is a season." I am well aware of at least some of the weaker aspects of my capacity and achievement. I am indeed very far from imagining that my achievement of what I wished and presented cannot be surpassed. From the start I have reckoned with the likelihood that one day with other means and methods everything might be done better than was possible for me. What possible right could I have to object - should I not rather rejoice for the sake of the cause, were I yet to see my advocacy of it overtaken and superceded?

Admittedly I could only regard myself as legitimately overtaken in this sense under the following conditions. A fresh theological programme must (1), however emancipated from my sketches, not betray their fundamental intention regarding the source, object and content of all theology worth the name, but carry it through in a better form. It must (2) prove itself to be a fresh programme by developing that fundamental intention in a way that points and leads forwards rather than backwards - inviting and encouraging the continuing Exodus from Egypt rather than something like the programme of the Jews back to that land in Jeremiah's later years. And it cannot (3) be just another mere "project" announcing itself ever and again in fresh garb. It must be brought under way in a reasonably consistent and complete form corresponding formally to what I have attempted to offer. I may have become hard of hearing, but so far the new song to sung to the Lord that would meet these conditions has not yet reached my ears. Thus with all modesty I would provisionally regard myself as not yet overtaken and superceded. However that may be: Dominus providebit. It only remains for me to wish for systematic theology (whatever may become of my contribution) in the nearer and further future that it may remain (or become again) the modest yet free, critical yet joyful enquiry which has become dear to me through all wanderings and temptations - and well worth all the trouble.

\section{Endnote}

Another version of this paper was published in the journal of the Protestant Theological Faculty of the Charles University in Prague, Communio Viatorum 42(3), 2000, 197-215. It is reprinted here with a few minor corrections and additions. A shortened version with the title "Karl Barth: A Personal Engagement" appeared in John Webster (ed), The Cambridge Companion to Karl Barth (Cambridge: Cambridge University Press, 2000), pp 296-306. 


\section{Works consulted}

Barth, K 1927. Die christliche Dogmatik im Entwurf, Bd. 1: Die Lehre vom Worte Gottes. Prolegomena zur christlichen Dogmatik. Münich: Kaiser Verlag.

Barth, K 1933. The epistle to the Romans. London: Oxford University Press.

Barth, K 1949. Dogmatics in outline. London: SCM Press.

Barth, K 1963. Evangelical theology . London: Weidenfeld and Nicolson.

Barth, K 1969. Letzte Zeugnisse. Zürich: EVZ-Verlag.

Barth, K 1977. Church dogmatics. Index volume with aids for the preacher. Edinburgh: T\&T Clark.

Barth, K 1991. The Göttingen Dogmatics, vol 1. Grand Rapids: Eerdmans.

Busch, E 1976. Karl Barth: His life from letters and autobiographical texts. London. SCM Press.

Busch, E 1986. Glaubensheiterkeit. Karl Barth: Erfahrungen und Begegnungen. 4.Aufl. Neukirchen: Neukirchener Verlag.

Cochrane, A C 1962. The church's confession under Hitler. Philadelphia: Westminster Press.

Cox, H E 1965. The secular city: Secularization and urbanization in theological perspective. London: SCM. Press.

Ericksen, R P 1985. Theologians under Hitler: Gerhard Kittel, Paul Althaus and Emanuel Hirsch. New Haven: Yale University Press.

Finke, A-K 1995. Karl Barth in Grossbritannien: Rezeption und Wirkungsgeschichte. Neukirchen: Neukirchener Verlag.

Freudenberg, M 1997. Karl Barth und die reformierte Theologie: Die Auseinandersetzung mit Calvin, Zwingli und den reformierten Bekenntnisschriften während seiner Göttinger Lehrtätigkeit. Neukirchen: Neukirchener Verlag.

Hamm, B 1998. Werner Elert als Kriegstheologe: Zugleich ein Beitrag zur Diskussion "Luthertum und Nationalsozialismus". KZG 11(2), 206-254.

Heppe, H 1950. Reformed Dogmatics set out and illustrated from the sources. London: George Allen and Unwin.

Heron, A I C 1971. Who proceedeth from the Father and the Son: The problem of the Filioque. SJT 24, 149-166. 
Höchstädter, W 1983. Durch den Strudel der Zeiten geführt. Bubenreuth: privately published.

Mensing, B 1998. Pfarrer und Nationalsozialismus: Geschichte einer Verstrickung am Beispiel der Evangelisch-Lutherischen Kirche in Bayern. Göttingen: Vandenhoek und Ruprecht.

Molnar, P D 1996. Karl Barth and the theology of the Lord's Supper. New York: Peter Lang.

Niebuhr, U M (ed) 1989. Remembering Reinhold Niebuhr: Letters of Reinhold and Ursula M Niebuhr. New York: HarperCollins.

Steinbauer, K 1983-1987. Einander das Zeugnis gönnen, vol. 1-4. Erlangen: privately published.

Zellweger-Barth, M 1986. My father-in-law: Memories of Karl Barth. Allison Park, PA: Pickwick Publications. 